\title{
SCHOOL-BASED STRATEGIES AND SUPPORT MECHANISMS THAT WILL FACILITATE FATHERS' INVOLVEMENT IN CHILDREN'S EARLY LEARNING: A QUANTITATIVE RESEARCH APPROACH
}

\author{
CHINEDU I.O. OKEKE ${ }^{1}$, MONSURU A. MUFUTAU ${ }^{2} \&$ CHRISTIAN S. UGWUANYI $^{3 *}$ \\ ${ }^{1}$ Host/Mentor, Professor, and Head, School of Education Studies, Faculty of Education, University of the Free State, \\ Bloemfontein, 9300, South Africa \\ ${ }^{2}$ Educator \& Researcher, Amazizi Senior Secondary School, Mpekweni, Peddie 5640, Eastern Cape, South Africa \\ ${ }^{3}$ Postdoctoral fellow, School of Education Studies, Faculty of Education, University of the Free State,
}

Bloemfontein, 9300, South Africa

\begin{abstract}
This study surveyed school-based strategies that will facilitate the fathers' involvement in their children's early learning based on a quantitative research approach. Using a sample of 94 participants, a descriptive survey design was adopted. Data were collected using a questionnaire instrument. Data were analyzed using mean and independent samples t-test. The results showed that the school-based strategies that can facilitate fathers' involvement in children's education include organising meetings for the fathers, contacting fathers on several occasions, school rendering counseling services to fathers among others. The result also indicated taking seriously fathers' suggestions, arranging get together party for fathers, among others are the school-based support mechanisms to encourage fathers' involvement in the education of children. The researchers recommend that the South African government should ensure that the identified school-based strategies and support mechanisms are fully implemented.
\end{abstract}

KEYWORDS: Children's Early Learning, Fathers'Engagement, Strategies, Support Mechanism

Received: Feb 17, 2021; Accepted: Mar 03, 2021; Published: Mar 22, 2021; Paper Id.: IJMPERDAPR202127

\section{INTRODUCTION}

Parental engagement has been highly placed as a major principle of good educational practice (Gileece, 2015; Johnson et al., 2016; Kavanagh \& Hickey, 2013; O’Toole, 2017; Ma et al., 2017). Buttressing the above assertion, the literature showed that parental engagement is highly associated with the improved behavior and wellbeing of children (Gileece, 2015). It has been found that parental engagement promotes positive academic outcomes (Hart, 2011; Hoover-Dempsey et al., 2001; Jeynes, 2005; Kim \& Hill, 2015).

Parental engagement is one of the key variables related to school effectiveness (Flouri, 2006; Flouri \& Buchanan, 2004; Ma et al., 2017). Research showed increased parental confidence, satisfaction, and interest in their education (Hornby \& Lafaele, 2011; Kiely, 2017; O’Toole, 2016). However, research have shown that the influence of parents on their children's education has not been producing the expected results (Harris \& Robinson, 2016; Robinson \& Harris, 2014). For instance, there was no significant correlation between parental engagement and children's test scores (Harris and Robinson 2016; Robinson and Harris 2014). This can be attributed to the fact that effective school-based strategies have not been properly identified and implemented. 
Studies have shown that the factors that contribute to effective parent involvement are support from peers (Reeves et al., 2015), informed practices based on culture (Fung \& Fox, 2014), problem-solving through collaboration (Knoche et al., 2012), using the approach of goal-setting sharing (Sheridan, Knoche, Edwards, Bovaird\& Kupzyk, 2010), and providing incentives for participation (Gross et al., 2011). In the United Kingdom, using cellular phone calls, texting, home visiting among others are the strategies for the active involvement of fathers in the education of their children (Henrich, 2013). According to Hnerich (2013), these strategies produced effective results for parental participation as well as maintaining effective communication for teachers and parents. Lindsey et al. (2014) found that comprehensive pretreatment assessment, accessibility promotion, homework assignments, and appointment reminders to the fathers are commonly used and successful strategies. In line with the above, Pellecchia et al. (2018) noted that efforts have been made to find out the effectiveness of engagement strategies across populations.

Further research have revealed that strategies to enhance fathers engagement include paying a home visit to fathers, organising games for father and teacher, and arranging for school debate among others (Okeke, 2014; Change, 2015; Mathwasa \& Okeke, 2016). Mathwasa (2019) opined that schools need to come up with family-friendly policies, where men play a significant role in school events. In such environments, schools plan and have regular events that bring families together with the school staff to collaborate in supporting children's learning and extramural activities. In Ethiopia, the government has a well-laid-down program for adequate fathers' involvement in their children's education (Woodhead, Rossiter, Dawes \& Pankhurst,2017). According to Dighe and Seiden (2020), early childhood development has what is known as home-based programs that help caregivers and parents create an environment that promotes learning at home. Based on the foregoing, it can be deduced that there is a dearth of literature on school-based strategies for improving the fathers' involvement in their children's education. This gap in literature necessitated the present research on the strategies and support mechanism for encouraging fathers' involvement in their children's education. Based on that, the following questions were posed.

- What school-based strategies encourage effective fathers' involvement in their children's education?

- What support mechanisms encourage effective fathers' involvement in their children's education?

\section{Hypotheses}

The following hypotheses were tested at 0.05 level of significance.

Ho1: Principals and teachers do not differ significantly in their mean ratings on school-based strategies that can encourage effective fathers' involvement in their children's education.

Ho2: Principals and teachers do not differ significantly in their mean ratings on school-based support mechanisms that can encourage effective fathers' involvement in their children's education.

\section{Methods}

\section{Research Design}

The design of the study was descriptive survey research. In similar studies, Okeke et al. (2020a, b), Eze et al. (2020), Okenyi et al. (2021), Ezema et al. (2021), and Ugwuanyi et al. (2020), have adopted the same design.

\section{Participants}

A sample of 94 respondents comprising 16 principals and 78 teachers participated in the study. The sample was 
drawn from a population of principals and teachers of pupils in Preschools (0-4years) and Grade R aspects of the foundation phase in King William's Town Education District in the Eastern Cape Province. The sample was composed using a multi-stage sampling procedure.

\section{Instrumentation and Procedure}

A questionnaire on the school-based strategies and support mechanism for fathers' engagement was used for data collection. The questionnaire had two clusters A \& B with 42 items. Cluster A had 24 items on school-based strategies while cluster B had 18 items on support mechanisms. A modified 4-point Likert rating scale of Strongly Agreed (SA), Agreed (A), Disagreed (D), and Strongly Disagreed (SD) was used. The copies of the questionnaire were administered to principals and teachers containing 42 items.

\section{Instrument Validation and Reliability}

Copies of the instrument were properly face validated by experts in instrument development. The validators were requested to look at the items of the instruments in terms of the clarity and suitability of the items concerning the study purposes and research questions. Thereafter, the instrument was trial-tested on 20 respondents outside the study participants. The internal consistency reliability indices of items of the two clusters of the instrument were obtained to be 0.75 and 0.82 using Cronbach's alpha method.

\section{Data Analyses}

Data were analyzed using mean and independent samples t-test. Mean was used to answer the research questions while independent samples t-test was used to test the lone null hypothesis at 0.05 level of significance.

\section{RESULTS}

\section{Research Question One}

What school-based strategies encourage effective fathers' involvement in their children's education?

Table 1: Mean Analysis of the Ratings of Principals and Teachers on the Strategies that Should be Provided by Schools to Promote Fathers' Involvement n=94

\begin{tabular}{|c|l|c|c|}
\hline S/N & \multicolumn{1}{|c|}{ Item Statement } & Mean & Std.D \\
\hline $\mathbf{1 .}$ & Ensuring that fathers are properly invited for meetings & 2.97 & .74 \\
\hline $\mathbf{2 .}$ & Maintaining contacts with fathers in case of any issue with their children & 3.17 & .50 \\
\hline $\mathbf{3 .}$ & $\begin{array}{l}\text { Ensuring that counseling services are rendered to fathers on ways of } \\
\text { supporting their children }\end{array}$ & 2.89 & 1.14 \\
\hline $\mathbf{4 .}$ & Providing home-school Liaison Officer by the school & 2.19 & .91 \\
\hline $\mathbf{5 .}$ & $\begin{array}{l}\text { Ensuring that fathers are highly encouraged to participate in children's } \\
\text { education. }\end{array}$ & 3.25 & .54 \\
\hline $\mathbf{6 .}$ & $\begin{array}{l}\text { Maintaining adequate communication with fathers concerning the } \\
\text { children's activities in school }\end{array}$ & 2.88 & .80 \\
\hline $\mathbf{7 .}$ & $\begin{array}{l}\text { Regularly arranging for meetings to talk with fathers about their children's } \\
\text { progress in school. }\end{array}$ & 2.54 & .87 \\
\hline $\mathbf{8 .}$ & Ensuring that story day activities are organised & 2.18 & .73 \\
\hline $\mathbf{9 .}$ & $\begin{array}{l}\text { Maintaining an encouraging language of expression in the school for } \\
\text { fathers }\end{array}$ & 2.60 & .75 \\
\hline $\mathbf{1 0 .}$ & Ensuring that motivational words are used to encourage fathers. & 2.93 & .58 \\
\hline $\mathbf{1 1 .}$ & Entertaining welcoming educational ideas from fathers by the school & 3.12 & .60 \\
\hline $\mathbf{1 2 .}$ & Reaching out to the fathers for the educational needs of the children. & 3.02 & .71 \\
\hline $\mathbf{1 3 .}$ & $\begin{array}{l}\text { Ensuring that fathers are encouraged to attend learners' programmes at } \\
\text { school at the scheduled time }\end{array}$ & 2.70 & 1.04 \\
\hline
\end{tabular}




\begin{tabular}{|c|c|c|c|}
\hline 14. & Ensuring that fathers are visited at home by the teachers & 2.07 & .84 \\
\hline 15. & $\begin{array}{l}\text { Ensuring that wide range of opportunities for fathers are provided by the } \\
\text { school }\end{array}$ & 2.54 & .87 \\
\hline 16. & $\begin{array}{l}\text { Ensuring that effective communication with the fathers is maintained by the } \\
\text { schools }\end{array}$ & 2.90 & .74 \\
\hline 17. & $\begin{array}{l}\text { Ensuring that fathers have easy access to school activities and programs by } \\
\text { creating a school website. }\end{array}$ & 2.40 & 1.01 \\
\hline 18. & Maintaining a sense of ownership of the fathers by the school & 2.46 & .85 \\
\hline 19. & $\begin{array}{l}\text { Making sure that fathers are giving opportunities to share their challenges } \\
\text { and successes }\end{array}$ & 2.92 & .59 \\
\hline 20. & $\begin{array}{l}\text { Arranging an open day with their children in which the fathers will be } \\
\text { invited }\end{array}$ & 2.67 & .79 \\
\hline 21. & Ensuring that Dad and Lads group is organised by the school & 2.17 & .69 \\
\hline 22. & $\begin{array}{l}\text { Ensuring that Home-School learning partnerships are established by the } \\
\text { school }\end{array}$ & 2.00 & .90 \\
\hline 23. & $\begin{array}{l}\text { Ensuring that friends-of-school society is established by the school for } \\
\text { fathers }\end{array}$ & 1.94 & .87 \\
\hline 24. & Making sure that fathers are trained as classroom assistants & 1.96 & .79 \\
\hline
\end{tabular}

Table 1 shows the mean ratings of the teachers and principals on the strategies that should be provided by schools to promote fathers' involvement. It reveals that the respondents agreed with the statements of the following items 1, 2, 3, 5, $6,7,10,11,12,13,15,16,18,19$, and 20 as the strategies that should be used to promote fathers' involvement in their children's education.

\section{Research Question Two}

What support mechanisms encourage effective fathers' involvement in their children's education?

Table 2: Mean analysis of the Ratings of Principals and Teachers on the Support Mechanisms that Encourage Fathers' Involvement n=94

\begin{tabular}{|c|l|c|c|l|}
\hline $\mathbf{S} / \mathbf{N}$ & \multicolumn{1}{|c}{ ITEMS } & \multicolumn{1}{|c|}{ Mean } & \multicolumn{1}{|c|}{ Std.D } & Decision \\
\hline $\mathbf{1}$ & $\begin{array}{l}\text { Maintaining effective communication between home and } \\
\text { school. }\end{array}$ & 3.26 & .79 & Mechanism \\
\hline $\mathbf{2}$ & $\begin{array}{l}\text { Conferences/Seminars should be organized by the school on } \\
\text { the roles fathers are expected to play }\end{array}$ & 2.63 & .88 & Mechanism \\
\hline $\mathbf{3}$ & $\begin{array}{l}\text { Ensuring that support groups' meetings are organized } \\
\text { regularly by the school. }\end{array}$ & 2.83 & .81 & Mechanism \\
\hline $\mathbf{4}$ & $\begin{array}{l}\text { Maintaining interest and cooperation with fathers to discuss } \\
\text { their children's problems. }\end{array}$ & 3.13 & .82 & Mechanism \\
\hline $\mathbf{5}$ & $\begin{array}{l}\text { Ensuring that the father's visitation is welcomed by the } \\
\text { school. }\end{array}$ & 3.25 & .70 & Mechanism \\
\hline $\mathbf{6}$ & $\begin{array}{l}\text { Ensuring that the father's suggestions are given adequate } \\
\text { attention. }\end{array}$ & 2.95 & .96 & Mechanism \\
\hline $\mathbf{7}$ & Ensuring that social gatherings are organised for fathers. & 2.40 & .99 & Not a mechanism \\
\hline $\mathbf{8}$ & $\begin{array}{l}\text { Making sure that fathers are invited to a special event by the } \\
\text { school. }\end{array}$ & 2.73 & .96 & Mechanism \\
\hline $\mathbf{9}$ & Making efforts to associate with children's fathers. & 2.63 & .98 & Mechanism \\
\hline $\mathbf{1 0}$ & $\begin{array}{l}\text { The school should provide the newsletter to seek fathers' } \\
\text { support and assistance. }\end{array}$ & 2.57 & .84 & Mechanism \\
\hline $\mathbf{1 1}$ & $\begin{array}{l}\text { Schools should organize workshops/seminars for fathers to } \\
\text { encourage their engagement. }\end{array}$ & 2.28 & .86 & Not a mechanism \\
\hline
\end{tabular}


Table 2: Contd.,

\begin{tabular}{|c|l|c|c|l|}
\hline $\mathbf{1 2}$ & $\begin{array}{l}\text { The schools should seldomly use phone communication for } \\
\text { fathers regarding the child's progress. }\end{array}$ & 2.40 & 1.04 & Not a mechanism \\
\hline $\mathbf{1 3}$ & $\begin{array}{l}\text { Ensuring that fathers are provided with concise and } \\
\text { meaningful information. }\end{array}$ & 3.05 & .88 & Mechanism \\
\hline $\mathbf{1 4}$ & $\begin{array}{l}\text { Making sure that a functional communication network } \\
\text { system is maintained between home and school. }\end{array}$ & 2.66 & 1.02 & Mechanism \\
\hline $\mathbf{1 5}$ & $\begin{array}{l}\text { Ensuring that separate programmes for working with fathers } \\
\text { are maintained by the school. }\end{array}$ & 2.16 & .89 & Not a mechanism \\
\hline $\mathbf{1 6}$ & $\begin{array}{l}\text { There should be school social workers in schools for family } \\
\text { support. }\end{array}$ & 2.27 & .90 & Not a mechanism \\
\hline $\mathbf{1 7}$ & Schools should make home visits. & 2.16 & .86 & Not a mechanism \\
\hline $\mathbf{1 8}$ & Ensuring that a calendar of activities is provided to fathers. & 2.38 & .88 & Not a mechanism \\
\hline
\end{tabular}

Table 2 shows the mean ratings of principals and teachers on the support mechanisms that encourage fathers' involvement. The analysis reveals that the principals and teachers agreed with the statements of the following items $1,2,3$, $4,5,6,8,9,10,13$, and 14 as the mechanisms that should be put in place to encourage fathers' involvement.

Ho1: Principals and teachers do not differ significantly in their mean ratings on school-based strategies that can encourage effective fathers' involvement in their children's education.

Table 3: t-Test Analysis of the Difference in the Ratings of Respondents on School-Based Strategies that Can Encourage Effective Fathers' Involvement in their Children's Education

\begin{tabular}{|l|c|c|c|c|c|c|}
\hline Respondent & n & Mean & SD & df & t & Sig \\
\hline Principals & 16 & 76.31 & 5.62 & \multirow{2}{*}{92} & \multirow{2}{*}{1.037} & .070 \\
\hline Teachers & 78 & 75.98 & 6.04 & & & \\
\hline
\end{tabular}

Table 3 shows that there is no significant difference in the mean ratings of principals and teachers on school-based strategies that can encourage effective fathers' involvement in their children's education, $t(92)=1.037, \mathrm{p}>0.05$. Therefore, both principals and teachers had the same views on the identified items as the school-based strategies to promote fathers' involvement in their children's education.

Ho2: Principals and teachers do not differ significantly in their mean ratings on school-based support mechanisms that can encourage effective fathers' involvement in their children's education.

Table 4: t-Test Analysis of the Difference in the Ratings of Respondents on Support Mechanisms that Can Encourage Effective Fathers' Involvement in their Children's Education

\begin{tabular}{|l|l|l|r|r|r|l|}
\hline Respondent & n & Mean & SD & df & t & Sig \\
\hline Principals & 16 & 72.71 & 9.34 & \multirow{2}{*}{92} & \multirow{2}{*}{1.19} & .069 \\
\hline Teachers & 78 & 71.89 & 8.93 & & & \\
\hline
\end{tabular}

Table 4 shows that there is no significant difference in the mean ratings of principals and teachers on their views on the support mechanisms that can encourage effective fathers' involvement in their children's education, $t(92)=1.19$, $\mathrm{p}$ $>0.05$. Therefore, both principals and teachers had the same views on the identified items as the support mechanisms that should be provided by schools to encourage fathers' involvement in their children's education. 


\section{Discussion of the Findings}

The findings of the study among other mechanisms revealed that the strategies that can be used by the schools to promote fathers' engagement are: ensuring that fathers are properly invited for meetings, maintaining contacts with fathers in case of any issue with their children, ensuring that counseling services are rendered to fathers on ways of supporting their children, providing home-school Liaison Officer by the school, ensuring that fathers are highly encouraged to participate in children's education, maintaining adequate communication with fathers concerning the children's activities in school among others. Similarly, it was found that the school support mechanism that can promote fathers' involvement includes maintaining effective communication between home and school, Conferences/Seminars should be organized by the school on the roles fathers are expected to play, ensuring that support groups' meetings are organized regularly by the school, maintaining interest and cooperation with fathers to discuss their children's problem, ensuring that father's visitation is welcomed by the school among others. These identified school-based strategies and support mechanisms if properly implemented will improve greatly the engagement of fathers in the early education of their children. These findings are in agreement with the findings of Lindsey et al. (2014), Okeke (2014), Change (2015), Mathwasa and Okeke (2016), Mathwasa (2019), Woodhead et al. (2017), and Dighe and Seiden (2020).

Lindsey et al. (2014) revealed that carrying out comprehensive pre-treatment assessment, offering accessibility promotion, giving homework assignments, and ensuring appointment reminders to the fathers are commonly used schoolbased strategies for enhancing fathers' involvement. Research had revealed that organising home visitation to fathers, scheduling games for parent and teacher, organising schools debate among others are the strategies to enhance fathers involvement (Okeke, 2014; Change, 2015; Mathwasa \& Okeke, 2016). Mathwasa (2019) found that schools implementing family-friendly policies, where men play a significant role in school events are an effective strategy for the active engagement of fathers. Woodhead et al. (2017) found that the introduction of parental education by the government improves the involvement of the children's education. Dighe and Seiden (2020) found that using home-based programs as strategies ensures that caregivers and parents maintain a conducive environment that promotes learning at home. In light of the above discussion, the findings of this study have several educational implications.

\section{CONCLUSIONS}

This study sought to determine the school-based strategies and support mechanisms for improving the fathers' involvement in the children's education. Thus, school-based strategies that can facilitate fathers' involvement in the children's education include maintaining contact with fathers in case of any issue with their children, ensuring that counseling services are rendered to fathers on ways of supporting their children, and providing home-school Liaison Officer by the school. Thus, it was recommended among others that;

- South African government should ensure that the identified school-based strategies and support mechanisms are fully implemented.

- A special day event should be organized for fathers to motivate them in taking active engagement in the education of their children.

\section{Limitation of the Study}

The sample size of this study may limit the generalizability of the findings. The fact that only eight schools of Foundation Phase classes were involved is a limitation. Thus, future researches can replicate the study by increasing the number of 
schools as well as respondents.

\section{REFERENCES}

1. Bakkabulindi, F. (2015). Positivism and interpretivism: Distinguishing characteristics, criteria and methodology. In C. Okeke \& M, Van Wyk (Eds.), Educational research: An African approach (pp. 19-38). Cape Town: Oxford University Press.

2. Bronfenbrenner, U. (1979). The ecology of human development Experiments by nature and design. Cambridge, MA: Harvard University Press.

3. Change, B. (2015). Reaching fathers. International Journal of Childbirth Education, 30(1): 9.

4. Cohort. British Journal of Educational Psychology, 76, 41-55. Flouri, E. and Buchanan, A. (2004). Early father's and mother's involvement and child's later educational outcomes. British

5. Dighe, S \&Seiden, J (2020). Understanding Parental Engagement in Early Childhood Education in Ethiopia: Perceptions, Practices, and Challenges. International Journal of Early Childhood. https://doi.org/10.1007/s13158-020-00262-8.

DOI: $10.31901 / 24566608.2019 / 65.1-3.3141$.

6. Eze, K.O., Ugwuanyi, C.S., \& Okeke, C.I.O. (2020). Extent of the Upper Basic Education French Language Curriculum Content-Delivery with Technologies in Nigerian Secondary Schools. International Journal of Mechanical and Production Engineering Research and Development (IJMPERD), 10(4): 311-318. https://doi.org/10.24247/ijmperdaug202027

7. Ezema, V.S., Okenyi, E.C., \& Ugwuanyi, C.S. (2021). Assessment of the extent of community involvement in the funding of primary schools in Enugu state, Nigeria: Implications for further research.International Journal of Mechanical and Production Engineering Research and Development, 10 (1), 91-98. URL:http://www.tjprc.org/publishpapers/2-671611554947-8IJMPERDFEB20218.pdf

8. Flick, U. (2015). Introducing research methodology (2nd ed.). Thousand Oaks, CA: Sage.

9. Flouri, E. (2006). Parental interest in children's education, children's self-esteem and locus of control and later educational attainment: Twenty-six year follow-up of the 1970 British Birth

10. Fung, M. P., \& Fox, R. A. (2014). The culturally-adapted early pathways program for young Latino children in poverty: a randomized controlled trial. Journal of Latina/o Psychology, 2, 131.

11. Gilleece, L. (2015). Parental involvement and pupil reading achievement in Ireland: Findings from PIRLS 2011. International Journal of Educational Research, 73, 23-36.

12. Gross, D., Johnson, T., Ridge, A., Garvey, C., Julion, W., Treysman, A. B., \& Fogg, L. (2011). Cost-effectiveness of childcare discounts on parent participation in preventive parent training in low-income communities. The Journal of Primary Prevention, 32, 283-298.

13. Harris, A. L., and Robinson, K. (2016). A New Framework for Understanding Parental Involvement: Setting the Stage for Academic Success. Russell Sage Foundation Journal of the Social Sciences, 2(5), 186-201.

14. Henrich, C. C. (2013). Commentary on the special issue on parent involvement/engagement in early childhood education. NHSA Dialog, 16 (1), 253-258.

15. Hoover-Dempsey, K. V., Battiano, A. C., Walker, J. M. T., Reed, R. P., DeJong, J. M. and Jones, K. P. (2001). Parental involvement in homework. Educational Psychologist, 36(3), 195-209. 
16. Hornby, G. and Lafaele, R. (2011). Barriers to parental involvement in education: An explanatory model. Educational Review, $3(1), 37-52$.

in Pre-schools: Implications for Policy and Practice. J Hum Ecol, 65(1-3): 65-74.

17. Johnson, S., Arevalo, J., Cates, C., Weisleder, A., Dreyer, B., and Mendelsohn, A. (2016). Perceptions about Parental Engagement among Hispanic Immigrant Mothers of First Graders from Low-Income Backgrounds. Early Childhood Education Journal, 44(5), 445.

Journal of Educational Psychology, 74, 141-153.

18. Kavanagh, L. (2013). A Mixed Methods Investigation of Parental Involvement in Irish Immersion Primary Education: Integrating Multiple Perspectives. (Unpublished doctoral dissertation). UCD, Dublin, Ireland,

19. Kiely, J. (2017). An internal process evaluation of The Storytime Project: A parental dialogic story-reading programme. (Unpublished doctoral thesis). Dublin City University, Ireland.

20. Knoche, L. L., Edwards, C. P., Sheridan, S. M., Kupzyk, K. A., Marvin, C. A., Cline, K. D., \& Clarke, B. L. (2012). Getting ready: results of a randomized trial of a relationship-focused intervention on the parent-infant relationship in rural early head start. Infant Mental Health Journal, 33, 439-458.

21. Lindsey, M. A., Brandt, N. E., Becker, K. D., Lee, B. R., Barth, R. P., Daleiden, E. L., \& Chorpita, B. F. (2014). Identifying the common elements of treatment engagement interventions in children's mental health services. Clinical Child and Family Psychology Review, 17, 283-298.

22. Ma, X., Shen, J., Krenn, H. Y., Hu, S., and Yuan, J. (2016). A metaanalysis of the relationship between learning outcomes and parental involvement during early childhood education and early elementary education. Educational Psychology Review, 28(4), $771-801$.

23. Mathwasa, J. (2019). Stakeholders' Views on the Participation of Male Educators

24. Mathwasa, J., \& Okeke, C. I. O. (2016). Barriers educators face in involving fathers in the education of their children at the foundation phase. Journal of Social Science, 46(30): 229-240.

25. Mncanca, M., Okeke, C. I. O., \& Fletcher, R. (2016). Black fathers' participation in early childhood development in South Africa: What do we know? Journal of Social Science, 46(3): 202-213.

26. O’Toole, L. (2016). A Bioecological Perspective on Educational Transition: Experiences of Children, Parents and Teachers. (Unpublished PhD Dissertation) Dublin Institute of Technology, Dublin Ireland. Available at https://arrow.dit.ie/appadoc/65/

27. O'Toole, L. (2017). A Bioecological Perspective on Parental Involvement in Children's Education. Conference Proceedings: The Future of Education, 7th Edition, 385-389.

28. Okeke, C.I.O. (2014). Effective home-school partnership: Some strategies to help strengthen parental involvement. SouthAfricanJournal of Education, 34(3): 1-9.

29. Okeke, C.I.O., Ugwuanyi, C.S\& Mufutau, M.A (2020a). Stakeholders' Views on Engaging Fathers in Early Childhood Care and Education. Journal of Human Ecology, 71(1-3): 177-186.https://doi.org/10.31901/24566608.2020/71.1-3.3233

30. Okeke, C.I.O., Okeke, C.C. \&Ugwuanyi, C.S. (2020b). Intervention strategies that can support young adults' transition into positive fatherhood: implications for Science, Technology, Engineering and Mathematics Education. International Journal of Mechanical and Production Engineering Research and Development (IJMPERD), 10(3): 8585-8596. https://doi.org/10.24247/ijmperdjun2020816 
31. Okenyi, E.C., Ngwoke, A.N., Ezema, V.S., Aneke, A.O., Asogwa, H.E., \&Ugwuanyi, C.S. (2021). Assessment of the perceived impact of home information and communication technology on pupils' social skills development. International Journal of Mechanical and Production Engineering Research and Development, $10 \quad$ (1), 67-78. URL:http://www.tjprc.org/publishpapers/2-67-1611120431-6IJMPERDFEB20216.pdf

32. Pellecchia, M., Nuske, H.J., Straiton, D.,.., \& Stahmer, A.C (2018). Strategies to engage underrepresented parents in child intervention services: A Review of effectiveness and co-occurring use. Journal of Child and Family Studies, 27:3141-3154. https://doi.org/10.1007/s10826-018-1144-y.

33. Reeves, G. M., Wehring, H. J., Connors, K. M., Bussell, K., Schiffman, J., Medoff, D. R., Tsuji, T., Walker, J., Brown, A., Strobeck, D., \& Clough, T. (2015). The family value of information, community support, and experience study: rationale, design, and methods of a "family-centered" research study. The Journal of Nervous and Mental Disease, 203, 896-900.

34. Robinson, K. and Harris, A. L. (2014). The Broken Compass. Cambridge, MA: Harvard University Press.

35. Sheridan, S. M., Knoche, L. L., Edwards, C. P., Bovaird, J. A., \& Kupzyk, K. A. (2010). Parent engagement and school readiness: effects of the Getting Ready intervention on preschool children's social-emotional competencies. Early Education and Development, 21, 125-156.

36. Ugwuanyi, C.C., Nwachukwu, W.C., Ugwuanyi, C.S., Okeke, C.I.O., Nworgu, B.G., Nwoye, M.N., Odo, I.O., Okeke, A.M., Inweregbuh, O.C., Osakwe, I.J. \& Idoko, J.U. (2020). Perceived Impact of the Use of Internet Resources on Undergraduate Students' Academic Achievement in Mathematics: Implication For Physics and Engineering Teaching. International Journal of Mechanical and Production Engineering Research and Development (IJMPERD), 10(4), 359-368. http://dx.doi.org/10.24247/ijmperdaug202031

37. Woodhead, M., Rossiter, J., Dawes, A., \& Pankhurst, A. (2017). Scaling-up Early Learning in Ethiopia : Exploring the Potential of O-class [Working paper]. Young Lives, Oxford Department of International Development (ODID), University of Oxford. 
